UDC 811.163.41’367.3

https://doi.org/10.18485/ms zmsfil.2021.64.2.4

Изворни научни рад

Миливој Алановић

\title{
ВАЛЕНЦИЈСКИ И ГРАМАТИЧКИ ОДНОСИ У СИНТАГМАМА*
}

\begin{abstract}
Главни задатак овога истраживања јесте да се скрене пажња да се исти тип валенцијских веза - комплементизација и суплементизација, иначе типичних за просту реченицу, успоставља и између регенса и депенденса унутар различитих типова синтагми, активирајући се као резултат рекције, конгруенције или прикључења. У уводном делу рада смо се, проверавајући валенцијске и граматичке односе, претежно ограничили на именичке и придевске синтагме, док је његов други део посвећен специфичностима глаголске валентности, посебно неличних глаголских облика од којих глаголски придеви заслужују посебан осврт, те граматичком статусу њихових сателита.

Кључне речи: српски језик, именска синтагма, валентност, комплементизација, суплементизација.
\end{abstract}

The main goal of this research is to point to the fact that the same type of valency relations - complementation and supplementation, otherwise typical for simple sentence - is established also between the head and its dependent in different types of phrases, being activated as a result of government, agreement or adjunction. In the introductory part of the paper we focused mostly on noun and adjective phrases, examining their valency relations and grammatical relations, while the second part deals with specificities of verb valency, especially non-finite verbal forms, among which verbal adjectives deserve special attention, along with the grammatical status of their satellites.

Key words: Serbian, noun phrase, valency, complementation, supplementation.

1. Увод. Теорија валентности је, добро је познато, у лингвистичком свету афирмисала истраживање управљачких способности финитног глагола у границама просте реченице (Welke 1988: 11, 115; ÀGel 2000: 7; HelBig 2002: 128, 130; Ружић 2006: 156), захваљујући чему је и стекла епитет вербоцентричног приступа. Истини за вољу, иако идеја водиља, вербоцентричност није начело прихваћено само у овој теорији, где у првом реду мислимо на генеративну и функционалну граматику, али је оваква теоријска оријентација одредила најужи круг истраживачких тема - у њеном фокусу нашле су се структурне и значењске везе међу реченичним члановима који гравитиpajy финитном глаголу - реченични модели (HeLBig 1992: 126-127; HeLBIG 2002: 130), што је за непосредну последицу имало да је несразмерно мало или пак недовољно пажње посвећивано валентности других речи, посебно именица и придева (ÀGEL 2000: 64; WELKE 1988: 115). Један од разлога који донекле оправдава ову тенденцију јесте да се исти тип валенцијских веза очекује и унутар конфигурација чији је центар именица или придев (WELKE 1988: 115), што свакако не значи да по истом обрасцу функционишу и реченица и синтагма

* Овај рад је настао у оквиру истраживања спроведеног на Филозофском факултету у Новом Саду које финансира Министарство просвете, науке и технолошког развоја Републике Србије. 
- именичка или придевска. Управо су због тога до данас остала актуелна бројна питања о видовима и облицима валентности других речи, међу која свакако спадају и она која се тичу ограничавања валенцијске способности именица само на комплементизацију (ÀGEL 2000: 59-60; Mrazović 2009: 327, 337), ${ }^{1}$ захваљујући чему изван детаљнијег описа остају сасвим уобичајене придевско-именичке синтагматске везе, типа висока јела, које се, иако хијерархијски устројене структуре, не објашњавају као израз валентности именице јела, о чему ће бити више речи касније, те се намеће питање који то онда механизам, ако не неки облик валентности, регулише овај тип зависног односа.

Последњи став никако не значи да се унутарсинтагматски односи нису посматрали депенденцијално, кроз призму релације између регенса и депенденса (TeSnière 1959; Engel 2009; Mrazović 2009). То је управо случај и код Л. Тенијера, који је врло детаљно описао структурне и значењске односе у именичким синтагма (TESNIÈRE 1959: 144-181), али оно што је важно истаћи јесте да ни он те везе не сагледава у светлу валентности речи. Наиме, сам Тенијер, дискутујући о глаголском стању на скоро педесет страна своје студије, изричит је у ставу да је валентност способност глагола да за себе веже одређени број актаната (TESNIÈRE 1959: 238). Како именице, полазећи од Тенијеровог схватања актаната, немају способност да уводе учеснике ситуације, тј. актанте, онда је разумљиво зашто се њихова валенцијска способност није ни узимала у разматрање. Дакле, иако корен интересовања за валенцијску способност глагола лежи у депенденцијалној граматици, ова појава је тек под окриљем теорије валентности детаљније разрађивана. Зато је на овоме месту, чини се, сасвим упутно осврнути се на фундаменталне разлике између ова два сродна теоријска правца - депенденцијалне граматике и теорије валентности. Док прва све структурне односе тумачи у светлу зависности међу речима, дотле ова последња заговара пројекционистички став, а то значи да у свакој структури мора постојати елемент чије присуство је неопходно да би се сама структура конституисала. Зато су, следећи начела ова два правца, и могућа сасвим различита тумачења односа унутар исте структуре, што илуструје једна могућа анализа веза у именичкој синтагми типа бела кощульа, по којој се управо придев сматра носиоцем валентности, јер је у питању предикат (WELKE 2011: 107-110). Овакво опредељење налази оправдање тек ако се има у виду да је ова придевско-именичка синтагма изведена из копулативне конструкције Кощуљља је бела. Штавише, и сам субјекат се у овом приступу поставља у сферу придевске валентности (WELKE 2011: 106-107), и то када у реченици имамо копулативну конструкцију типа је йреслайка, нпр. у Торйа је ирреслайка. ${ }^{2}$

\footnotetext{
${ }^{1}$ Павица Мразовић је у својој граматици доста пажње посветила именичким и придевским сателитима у одговарајућим синтагмама, али и она само допуне сматра изразом валентности главне речи (Mrazović 2009: 327, 337). Уз то, у овом приступу се структурне операције попут рекције или конгруенције не разматрају као критеријуми диференцијације допуна и додатака.

${ }^{2}$ Ми смо стајалишта да овакав приступ има више недостатака, а главни је - шта се дешава са именицом уз коју не стоји придев или неки детерминатив. Наиме, ако је именица сателит личног глагола, тешко да може бити у исто време и резултат придевске валентности,

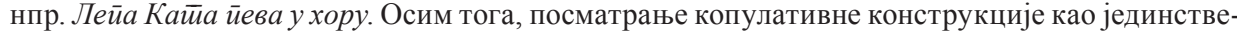
ног носиоца валентности иде на рачун крњења валентности копулативног глагола, при чему
} 
Међутим, како ни у самој теорији валентности не постоји опште јединство о томе која јединица је носилац валентности у придевско-именичким синтагмама и копулативним конструкцијама, у наставку рада ћемо се чвршће ослонити на депенденцијалне односе, за које сматрамо да боље откривају логику унутрашње организације најразличитијих структура.

Из тога разлога се чини више него оправданим проблематизовати управо питање валенцијских веза у синтагмама у српском језику, нарочито из перспективе једне пројекционистичке теорије каква је теорија валентности, те проверити да ли су и на овом нивоу језичке структуре главни механизми њенога извођења комплементизација и суплементизација. Премда смо већ на известан начин наговестили интересовање за именичке и придевске синтагме, без коментара или осврта не могу остати ни глаголске, посебно оне које конституишу глаголски придеви, јер је важно указати на разлику у активирању валентности глагола када је у личној и када је у неличној форми, што има непосредног утицаја и на интерпретацију унутарсинтагматских граматичких веза. Међутим, сматрамо да овако постављен теоријски оквир искључује потребу да се у раду расправља о различитим аспектима променљивости глаголских придева у српскоме језику, на шта су већ дати валидни одговори, и то у погледу порекла саме категорије (БЕлић 1999: 468-469), затим семантичких ограничења која регулишу прелазак у категорију правих придева (БЕлић 1934: 36-37; СтевАнОвић 1940: 205; СтевАновић 1958: 88), потом творбених механизама настанка, морфолошког описа и лексикографске обраде (ТАFRА 2005: 100; СПАСОјЕвић 2011: 25, 27; НовокмЕт 2013: 66-74).

2. ВАЛЕНЦИЈСКИ МЕХАНИЗМИ У РЕЧЕНИЧНОМ И СИНТАГМАТСКОМ ОКВИРУ. Већ смо изнели став да се истоветне везе успостављају како међу реченичним тако и међу синтагматским члановима, што подразумева да се на оба ова структурна плана виде резултати два кључна валенцијска механизма - комплементизације (допуњавања) и суплементизације (додавања), који и иначе служе за грађење или извођење најразличитијих типова конструкција (ЕRомS 2000: 122, 267, 280, 286; Mrazović 2009: 327, 337; Pafel 2011: 42). Овоме као доказ наводимо примере који чине два саодносна типа структура, реченицу и њен номинализовани израз, нпр. Ана чийа новине у библиойеци и Анино чийање новина у библиойеци, где и у једном и у другом видимо облике са сталном и с несталном формом, што и јесте у бити појаве о којој је реч.

Подсећања ради, допуне су непосредан израз комплементизације, док су додаци уведени као резултат суплементизације. Иако је било више различитих покушаја да се и једне и друге валенцијске јединице прецизније одреде (HeLBIg 2002: 146-148), чини се да је преовладао став да су допуне формалноспецифичне и, у начелу, синтаксички обавезне јединице, док су додаци формалнонеспецифичне и синтаксички слободне јединице (ÀGEL 2000: 205, 211). ${ }^{3}$ Последње значи да регенс предодређује форму а тиме и

се исти однос тешко може применити и када је реч о копулативним прилошким конструкцијама, нпр. Ана је gобро.

${ }^{3}$ Павица Мразовић, по угледу на У. Енгела, другачије утврђује односе између рекције и валентности. У овом моделу је рекција депенденцијална веза, што значи да се активира у 
функцију свога комплемента или допуне, док када је реч о суплементима или додацима, њихова формална обележја остају релативно слободна, нпр. разіовор о роману према разіовор у йоgне / иосле ручка итд. Подразумева се да ту и тамо има случајева који измичу овако успостављеној дихотомној подели, што ипак не угрожава њену теоријску и методолошку заснованост и оправданост. Тако су, на пример, од реченичних чланова граматички субјекат и објекти допуне, док су адвербијали додаци, а главни разлози за то су следећи:

(a) форма граматичког субјекта и објеката унапред је задата или позната, док њихово евентуално испуштање из реченичнога контекста није сигнал факултативности већ контекстуалне познатости, нпр. Долазим и Јеgем;

(б) форма адвербијала није унапред задата и готово доследно је реч о факултативним члановима, нпр. Сеgим gо ње / ближе мост̄и / йpeg кућом / на иирему.

2.1. Како се поменути класификациони критеријуми у основи ове дихотомне поделе, уз неке већ описане изузетке - нпр. обавезне адвербијале, или тзв. прилошке допуне или адјункте (СтАнолчић - Поповић 2014: 253; АлАновит 2012: 160), доследно могу пратити и на нивоу различитих типова синтагми, јер се комплементизација и суплементизација смењују или удружују и на овом нивоу језичке структуре, то значи да је теоријски утемељено говорити о синтагматским допунама и додацима (MRAZović 2009: 327, 337). Остаје да се провери којим се структурним операцијама ова два валенцијска механизма и у оквирима синтагме испољавају, при чему мислимо на рекцију, конгруенцију и прикључење (ЗолотовА 2009: 32; ПиПЕР - КлАлн 2013: 266). Међутим, пре него што се позабавимо овим проблемом, треба се накратко осврнути на специфичности именичке и придевске валентности, посебно у односу на глаголску.

Теорија валентности се током свога развоја суочавала с различитим изазовима, од којих је један од важнијих био уврежен став да су само допуне израз глаголске валентности (WeLKe 1988: 14-15; ENGEL 2009: 71; WelKe 2011: 45). Доследно праћење овога начела подразумевало је да додаци нису убрајани у валенцијске јединице. Јасно је да је овакав приступ означио теоријску и методолошку странпутицу, јер се супроставља логици саме науке по којој научни инструментаријум треба да буде применљив на све јединице.

На тај начин је негован принцип да именице као ойаџ, мајка, кућа и

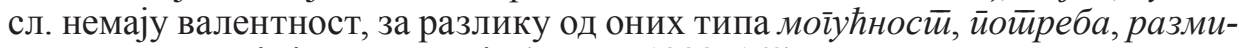
üљаље и др. које је испољавају (WELKE 1988: 162). Практична примена овако формулисанога начела значи да оне прве не показују валентност ни када конституишу именичке синтагме типа нежна мајка, што намеће сасвим

\footnotetext{
сваком случају када се региструје однос између регенса и депенденса. С друге стране, способност селекције одређене врсте сателита имају само они регенси који захтевају реализацију - допуне. Тако су само допуне израз валентности регенса, док су и допуне и додаци уведени као резултат рекције одговарајуће главне речи (Mrazović 2009: 38). Сматрамо, међутим, озбиљним недостатком што се валентност не сагледава и кроз структурне операције, које материјализују валенцијску способност регенса. Осим тога, и у овом приступу се комплементизација превасходно веже за обавезност реализације сателита, укључујући и обавезне детерминаторе.
} 
оправдано питање: Шта онда у именичим синтагмама регулише присуство конгруентних атрибута? Опредељење да је у домену именичке валентности, као уосталом и глаголске, само комплементизација свесно или несвесно је ограничило научни домет саме теорије, јер је изван њенога домашаја остао читав низ синтаксичких веза на различитим нивоима језичке структуре.

Управо зато се као далеко примереније решење наметнуо приступ по којем се веза између регенса и депенденса може испољити у различитим видовима, нпр. синтаксичком и/или семантичком - неке везе су доминатно синтаксички а неке семантички условљене, ${ }^{4}$ тако да је и теоријски далеко смисленије и методолошки оправданије све ове односе сагледавати у контексту валентности речи (WeLKE 1988: 74-75, 79-83; АлАновић 2019: 139). Томе следствено, именице типа кућа испољавају семантичку валентност, нпр. *брза кућа према мала кућа итд., будући да се именички регенс и његов депенденс семантички усаглашавају. Истина, ове две јединице се усаглашавају и синтаксички, у виду конгруентног односа, што је још један доказ за то да је озбиљна теоријска и методолошка омашка нерекцијским именицама ускратити валенцијску способност.

На истоветан се начин дају сагледати и односи унутар придевских син-

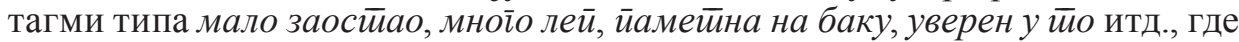
су једни семантички а други синтаксички условљени. Стога за придеве типа лей кажемо да имају семантичку, док за придеве типа уверен да испољавају синтаксичку валентност, јер се ова темељи на рекцијском односу између регенса и депенденса.

Ако имамо у виду поменута два типа валентности - синтаксичку и семантичку (VAN VALIN - LA POLLA 1997: 147), примећујемо да је управо она синтаксичка у најтешњој вези с комплементизацијом. Наиме, комплементизација је израз депенденцијалне везе засноване на рекцији као најчистијем појавном облику зависности, нпр. рещавање ирроблема, йомоћ йријайељу, разїовор о роману, свестиан свеі̄a, заgовољан нечим итд. С друге стране, нерекцијске везе проистичу из семантичке компатибилности између регенса и депенденса, које су у језику материјализоване у форми конгруенције и при-

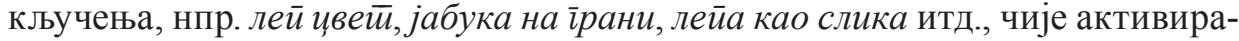
ње зависи од категоријалних обележја главне речи. Све речено подржава раније изнето мишљење да се и унутар именичких и придевских синтагми региструју везе настале или као резултат комплементизације (допуњавања) или као резултат суплементизације (додавања), при чему се подразумева да се и један и други механизам могу активирати истовремено, нпр. њеі̆ова

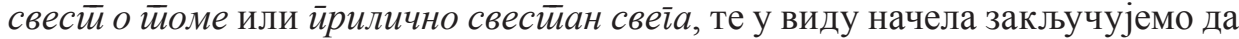
је рекција израз комплементизације, нпр. йомисао на нещйо или сирреман на све, док се суплементизација испољава у виду конгруенције, нпр. слайка

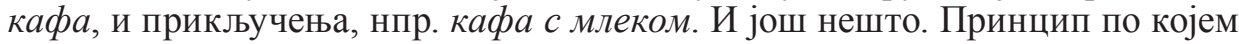
се зависни чланови именских и прилошких синтагми третирају као атрибути (ENGEL 2009: 79) на овај начин и даље није изгубио упориште у теорији

${ }^{4}$ Сагласни смо с В. Ружић да је допуна синтаксичко-семантичка категорија (Ружић 2006: 159), што у неку руку важи и за додатке, али не треба посебно истицати да су допунама њихова формална обележја унапред утврђена, што није случај с додацима. 
валентности, јер је семантички мотивисан, што не угрожава ни чињеница да конгруентни и неконгруентни атрибути имају различит валенцијски статус - први су суплементи, док су други или суплементи или комплементи, у зависности од тога да ли неконгруентни атрибут задовољава рекцију главне речи (разі̄овор о роману) или јој је просто придодат или прикључен (разі̄oвор у кафићу).

Потпун опис какве структуре у теорији валентности подразумева и приказ у виду депенденцијалног стабла или дијаграма. Ако пак сачинимо дијаграм, у који ћемо распоредити лексичко-граматичке елементе примера зиgағе куће на класичан начин, његова структура открива само односе зависности међу синтаксичким јединицама, али не и тип валенцијског односа:

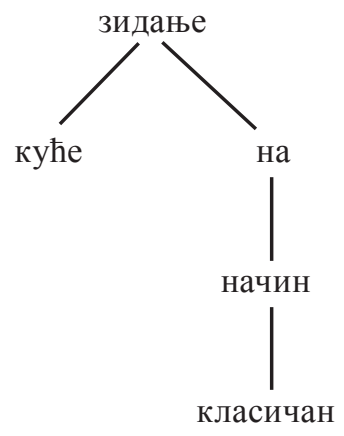

Наиме, глаголска именица зияане управна је реч синтагме, а њени непосредни сателити јесу именица куће и предлошка конструкција на класичан начин, у којој се опет налази именичка синтагма класичан начин, што је тренутно изван наше пажње. Када је реч о сателитима, међу њима постоји битна разлика - именица куће уведена је као резултат рекције, и то категоријалне, ${ }^{5}$ будући да именица зияање као регенс предодређује њен генитивни облик. С предлошком конструкцијом ствари су сасвим другачије, њену форму не успоставља именица зиgање, а и присуство јој је у структури факултативно, нпр. хоgање / црйање на класичан начин итд. Зато је и следећи закључак крајње логичан: облик куће има статус допуне, док је конструкција на класичан начин додатак, без обзира на то што именичка допуна, знатно чешће од оне глаголске, може остати нереализована, нпр. Бави се зияањем.

Очигледно је да се готово идентичан однос види и у границама одговарајуће реченице, нпр. Зияамо кућу на класичан начин, али на опрез позива чињеница да именичке синтагме ипак другачије функционишу, а под тим мислимо на могућу синтаксичку синонимију између конгруентних и неконгруентних атрибута. Тако, именичке синтагме долазак Марка синоћ и Марков синоћни gолазак израз су синтаксичке заменљивости у коју ступају допунски и додатни атрибути, и то захваљујући не у свакој прилици расположивој језичкој могућности да се наместо неконгруентног употреби конгруентни

\footnotetext{
${ }^{5}$ Под категоријалном рекцијом се мисли на рекцијска својства целе једне класе речи (EISENBERG 2013: 32). Тако, глаголске именице у српском језику имају генитивни тип рекције као општу одлику. Други облици рекције глаголских именица условљени су њиховим лексичкосемантичким обележјима.
} 
атрибут. Без обзира на евентуална системска ограничења, ова алтернација доказује темељну природу атрибуције као синтаксичко-семантичког поступка у језику, а то је да и допунски и додатни атрибути имају исту сврху - да садржајем испуњавају какав појам, односно да служе за употпуњавање представе о каквом појму. На овај закључак недвосмислено наводе и конкурентни

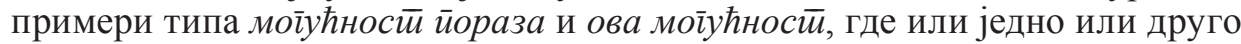
расположиво језичко средство оверава комуникативну прихватљивост конструкције, што није ресурс који допушта замену глаголских допуна, нпр. чийайи новине сваки яан.

На сличан начин се очитавају односи у депенденцијалном стаблу с придевском синтагмом. Нпр.:

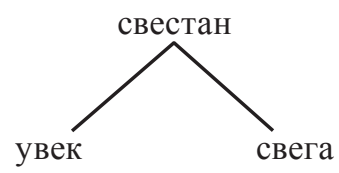

И овде логика депенденцијалног стабла показује зависне односе, док се евентуално на основу позиције у дијаграму може претпоставити да ли је реч о суплементу (увек) или комплементу (свеі̄a), али без потпуне поузданости. Због категоријалне специфичности придева за њих се у функцији додатних атрибута углавном везују прилози, предлошке конструкције или

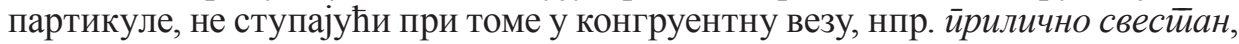

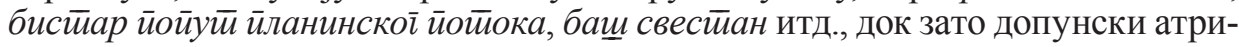
бути, као и уз именичке регенсе, доследно показују обележје формалне специфичности, тј. падежне предодређености, нпр. gосӣојан чеїа, йойребан коме, сиреман на све, заяовољан нечим, дослеgан у свему итд. Но, овде бележимо једну специфичност - придеви попут брз, лей, висок, мрщияв итд. нису рекцијске речи, јер имају само семантичку валентност, нпр. врло лей, висок

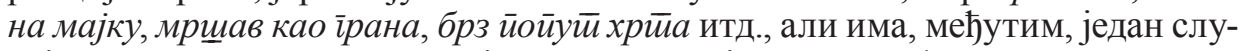
чај где и ови придеви захтевају допуне, а то је када су у форми компаратива или суперлатива, нпр. Бржи је оg обојище или Највища је og свих, те отварају место за поредбену допуну у генитиву (ENGEL 2009: 103).

И овде се намеће питање о томе у којој мери је присуство придевских допуна обавезно, а у те сврхе можемо упоредити примере Она је вреgна и Она је вреgна наще йажне, те Она је свесна и Она је свесна свеі̄a. У првом пару примера среће се придев вреgна, али с два различита значења - 'марљива' и 'достојна', где оно друго предвиђа обавезно присуство допунског атрибута, будући да придев вреgна има улогу модалног оператора (АлАновић 2018: 125). На сличан начин се понаша и придев свесна у друга два примера, с том разликом да је у последњем употребљен као предикатор (АлАновић 2018: 124), будући да је у значењској вези с глаголом знайи, што опет захтева обавезну реализацију допунског атрибута у генитиву. Стога констатујемо да предикаторска или модално-операторска улога придева, ако пак потпуно не искључује, битно ограничава испустивост допунских атрибута у синтагми.

На самоме крају се треба сетити једнога случаја у српској синтакси који ствара немале недоумице, а то је обавезна реализација детерминатора у структурама типа gечак йлаве косе (RAdovAnović 1990: 78). Добро познат 
пример за чије је граматичко обликовање решење пронађено у теорији прототипа. Ипак, остаје питање да ли је придев йлаве допуна или додатак, с обзиром на то да оверава граматичност целе конструкције, нпр. *gечак косе. Иако појмовни опсег термина семантичка допуна није сасвим прецизно одређен у српској синтакси (Антонић 2005: 131, 210-211), он је овде сасвим примерен, што пак искључује могућност да је реч о допунском типу атрибута, будући да ни именица gечак ни именица коса нису рекцијске речи. Обавезно присуство придева йлаве у структури условљено је принципима обликовања овог типа конструкције те правилима семантичког усаглашавања депенденса с регенсом. Специфичност структуре са обавезним детерминатором само наизглед иде у прилог ставовима да се преко концепта обавезности може објаснити место допуна у граматичком систему, упркос чињеници да је превише недоследности у оваквом приступу (уп. случајеве без реализованог субјекта и објекта, нпр. Пищем). Зато се и сам А. Белић својевремено определио за падежни израз као темељно обележје допуна (БЕлић 1998: 135), што је касније у теорији влентности формулисано у виду правила формалне специфичности, јер се испустивост сателита у већини случајева повезује са семантичким и комуникативним факторима обликовања исказа.

2.2. У претходним параграфима смо, када је реч о граматичком статусу сателита уз именске речи, констатовали да имају функцију атрибута, допунскога или додатнога, што нас доводи у озбиљну недоумицу да ли се посве исте везе остварују и у примерима типа сйвари оgузете заивворенику йриликом хайщељ $a$, у чији састав улази синтагма конституисана око глаголског придева. Иако је реч о попридевљеноме глаголскоме придеву, велико је питање да ли се приликом анализе овога примера сме сметнути с ума порекло ове категорије, односно чињеница да веза с глаголом од којег је изведен није прекинута, што и структурно-значењске везе у синтагми показују.

Структурне везе у одговарајућем дијаграму изгледају овако:

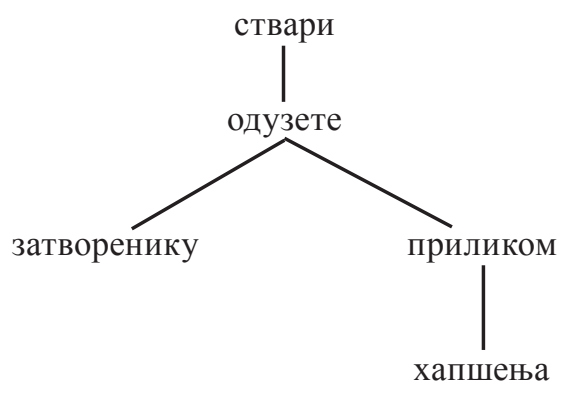

Како видимо, хијерархијски односи у последњем стаблу се представљају као и у свакој другој именској синтагми, или чак реченици, где нема посебних ознака за граматичку функцију или значењску реализацију сателита. Ово је отуда што се у депенденцијалном стаблу доследно могу пратити само зависне везе.

Раније смо рекли да се, у складу с начелима овога правца, атрибути дефинишу као зависни чланови именских и прилошких синтагми: слайка крущщка, 


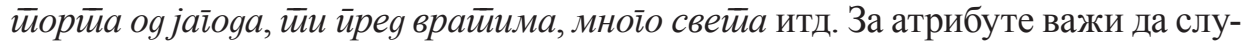
же да се неки појам класификује, тачније квалификује или категоризује, мада има примера где се овим јединицама сам појам уводи у ситуацију, такве су управо прилошке синтагме попут мноїо хлеба, што говори да су значењски односи унутар синтагме с атрибутом у другом плану у односу на оне структурне. Иако није неочекивано да се у самој дефиницији истиче категоријална припадност управне речи синтагме која отвара место за одређени атрибут, остаје дилема зашто овом правилу не подлежу глаголске синтагме типа йоклонийи незнаниу бицикл.

Нелични глаголски облици не конституишу самостално предикат јер нису у стању да реченици обезбеде персоналну парадигматичност. У основи ове правилности лежи једна важна одлика глагола, а то је да ове његове форме не отварају место за субјекат у реченици, што значи да нелични глаголски облици не активирају у потпуности валенцијски потенцијал глагола, будући да имају само десну валентност, нпр. рекавщи свима щйио зна итд. Наведена валенцијска својства треба имати у виду само због једне чињенице, а то је да се десна валентност, по правилу, чува било да је употребљен у личној било да је употребљен у неличној форми (ЕROMS 2000: 275-276; ENGEL 2009: 105), нпр. Чийам новине и чийайи новине, Рекао им је све щитио зна и рећи све uㅡo зна итд. Истине ради, глаголски придеви показују неке специфичности, али о томе нешто касније.

Дакле, ако глаголи чийайи и рећи и у презенту и у инфинитиву показују исти облик десне валентности, што је случај и када су у улози централног глагола у сложеним предикатима или сложеним глаголским облицима, попут је морао рећи или ће рећи и сл., нема никаквог разлога њихове допуне различито третирати, као објекте и као атрибуте. Разлика међу овим допунама лежи само у типу структуре у којој су реализоване - у реченици или у синтагми, тако да једном говоримо о реченичном а други пут о синтагматском објекту. Исти се односи прате и у синтагмама с глаголским прилозима, нпр. ущщавщи у раяюу, слаїавщи рояииееље о йоме итд., тако да се, са изузетком граматичког субјекта, остале реченичне функције реализују и у границама глаголских синтагми. Међутим, како ствари стоје са номинализованим изразима? Иако се наизглед знак једнакости у погледу синтагматских односа може ставити између читиайи новине и чийање новина, језик се постарао да другачији граматички однос адекватно формализује, и то у виду конверзије синтагматског објекта у акузативу уз инфинитив у допунски атрубут у генитиву уз глаголску именицу, нпр. чийайи новине - чийање новина. И коначно, да ли се ово правило односи и на глаголске придеве?

Како бисмо на постављено питање дали поуздан одговор, најбоље је да кренемо од именичких синтагми с глаголским придевима, нпр. сиивари йреgатее на чување gомару и суйа искийела из лонща. Као што се види, овде не разматрамо примере њихове глаголске употребе, дакле, када су у саставу сложених глаголских облика.

Оба глаголска придева, и радни и трпни, употребљени су придевски те

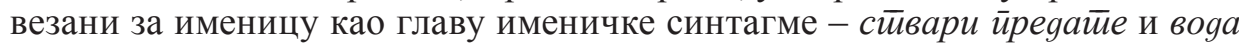
искииеела, у односу на коју врше атрибутску фукцију (БЕлић 1934: 36, 39; СтевАновић 1940: 196; 1962: 202), што и конгруентна веза са њом потврђује. Без 
обзира на глаголско порекло ових придева (први од непрелазног а други од прелазног и свршеног глагола [в. БЕлић 1934: 38-39]), усаглашавање њихове форме према регенсу указује да им је улога да се ближе одреди представа идентификована управном именицом, која означава или субјекат или објекат радње (СтевАновић 1940: 197; 1958: 88), што не изненађује, јер и као делови сложених глаголских облика конгруирају у роду и броју са субјектом активне или пасивне реченице - Сйвари су йреgайе и Boga је искийела. Конгруенција у падежу резултат је конверзије глаголске у именску реч, али недоумице пак стварају сателити које уводе ови придеви, нпр. йреgат̄е на чување gомару и искииела из лонца.

Придевски сателити на чување и gомару, односно из лонца, задржавају иста формална обележја и у синтагми као и у реченици из које су изведени, нпр. Сйвари су йреgайе на чување gомару и Суйа је искийела из лониа. Ова аналогија потврђује да су посматране придевске синтагме редуковане клаузе.

ствари предате на чување домару

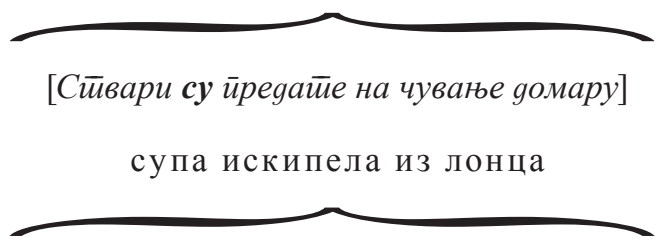

[Суйа је искийела из лониа]

Међутим, номинализација ове две предикације није изведена сасвим по истом моделу, што зависи од категоријалних обележја глагола који лежи у твобеној основи придева, трпног и радног.

Придевске синтагме везују се за именичку главу која у исходишној, или дубинској/базичној реченици, има функцију граматичког субјекта, при чему се у једном случају ради о пасивној а у другом о активној реченици (EISENBERG 2013: 334). Тако је трпни придев оператор пасивне а радни оператор активне дијатезе. Сада видимо зашто су категоријална обележја глагола важна за конституисање целе синтагме. Глава именичке синтагме у чијем је саставу синтагма коју уводи попридевљен трпни придев јесте директни објекат одговарајућег прелазног глагола, нпр. с йвари нађене - наћи сиивари. Сасвим је другачија ситуација у синтагми с попридевљеним радним придевом - глава ове именичке синтагме је субјекат непрелазног глагола, нпр. искийела воgа - воgа је искийела. Из претходнога следи да глава овог типа именичке синтагме може бити само један од два централна глаголска аргумента - субјекат или директни објекат.

Осим тога, у овим синтагмама се налазе и други глаголски сателити, индиректни објекат, адвербијал и сл., и то у неизмењеној форми, што све заједно узев истраживача ставља пред следећу дилему - како описати синтаксичке односе унутар овог типа придевске синтагме. Напомињемо, није занемарљива чињеница да није у питању прави већ глаголски придев, јер, без обзира на то што је у новом граматичком окружењу, овај придев делимично и даље чува облик глаголске валентности, што се нужно мора одразити и на синтак- 
сичке везе међу синтагматским члановима. Дакле, кључно питање остаје јесу ли зависни чланови синтагми које конституишу попридевљени глаголски придеви њихови атрибути. Сматрамо да одговор на ово питање не може бити потврдан, премда су аргументи за ову тврдњу углавном посредни, а они су:

(a) именичка синтагма у коју је укључена синтагма с глаголским придевом као регенсом представља трансформ дубинског пропозиционог садржаја;

(б) формална обележја сателита остају непромењена, без обзира на то у који тип структуре је интегрисан глаголски придев;

(в) и када је део сложеног глаголског облика, глаголски придев је централни глагол те тиме носилац валентности у реченици;

(г) прелазак у категорију правих придева нужан је због природе везе с именичким регенсом, што се последично не може одразити на граматички статус сателита унутар придевске синтагме;

(д) сателити придевске синтагме не стоје ни у каквој синтаксичко-семантичкој вези с именичким регенсом.

Ако све речено имамо у виду, јасно је да се сателити унутар синтагми које чине глаголски придеви морају третирати на исти начин као и у другим глаголским синтагмама, нпр. инфинитивним. Дакле, у питању су синтагматски објекти, адвербијали и сл. Занимљиво је, међутим, да би доследно праћење начела теорије валентности по којима се уместо термина субјекай или

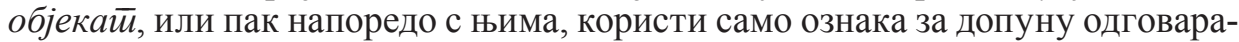
jућег реда, нпр. $\mathrm{E}_{\text {ном }}$ или $\mathrm{E}_{\text {ак }}$ (ENGEL 2009: 134), омогућило да се, без терминолошког конфликта, означи исти тип граматичких веза и на реченичном и на синтагматском нивоу - нпр. за реченични и синтагматски објекат, што само по себи не води било каквој контрадикторности у опису.

3. ЗАкључАк. Све наше опсервације изнете у овоме раду потврђују неколико полазних теза: прво, више је него оправдано теоријски концепт валентности проширити са структурног на семантички план реченичне и синтагматске организације, све с циљем да се обухвате све јединице које чине непосредно окружење регенса, чиме би се избегла теоријска и методолошка замка по којој додаци (или суплементи/одредбе) бивају изузети из детаљнијег описа; и друго, у којој мери је овај приступ плодотворан доказује чињеница да се истоветни односи прате подједнако у реченичном као и у синтагматском оквиру. Управо је последња теза и била у средишту наше пажње, при чему смо указали да се исти валенцијски механизми активирају како међу реченичним тако и међу синтагматским члановима, разуме се у односу регенс - депенденс, а то су комплементизација и суплементизација. Осим тога, као што је то случај и у реченичном оквиру, за позиционирање синтагматских депенденса одговорне су три структурне релације, а то су рекција, конгруенција и прикључење, где она прва омогућује увођење допуна, док су последње две одговорне за укључивање додатака.

Без обзира на све сличности у структурирању реченице и синтагме, не треба сметнути с ума да реченица, коју карактерише динамичност, реферише о некој ситуацији, док синтагма, коју пак одликује статичност, даје податак о сталности какве представе (БЕлић 1998: 123). Зато и не изненађује појава да 
унутар именичких синтагми и комплементизација и суплементизација превасходно служе у сврхе детерминације управне речи, нпр. йойреба за храном и ова йойреба, што доказује да су значењске везе унутар реченице и именичке синтагме другачије профилисане. Штавише, ова се специфичност даље рефлектује и на успостављене граматичке везе у овим двема структурама.

Наиме, други део рада је био доминантно посвећен утврђивању граматичких односа у именичким и глаголским синтагмама, за које се може рећи да су предоређени типом главне речи, а то значи да се један граматички тип депенденса реализује у именичким а други у глаголским синтагмама, чак и у оним које конституише глаголски придев. Иако је утемељено тврдити да у основи ове разлике леже значењске специфичности, оличене у односу представа - ситуација, немогуће је занемарити обележја и посебно порекло језичких категорија, нарочито у случају глаголских придева. Тако, ако се има у виду да је централни глагол, или носилац валентности, у реченици са сложеним глаголским обликом управо нелични глагол, онда се сам по себи намеће следећи закључак: валентност глагола употребљеног у личној и неличној форми минимално се разликује - нелични облици немају леву валентност, што искључује реализацију субјекта. Ипак треба додати да овај 'субјекат' (заправо дубински или пропозициони) није у реченици изгубљен без трага, измештањем из придевске реализован је на позицији главне речи именичке синтагме - сйвари нађене на улици [Ствари су нађене на улици]. Још једна непосредна последица овога правила јесте да се објекти и адвербијали реализују и на реченичном нивоу и унутар глаголских синтагми. С друге стране, како именице и њихови алтернанти означавају представе, депенденси ових синтагми су - атрибути, конгруентни или неконгруентни, било да су уведени посредством комплементизације било да су резултат суплементизације. Због овога се не могу, ни граматички ни логички, изједначити сате-

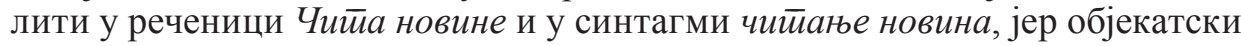
генитив има само једну улогу - да се употпуни представа о процесу, нпр. чит̄ање новина ме ойущй̄a.

\section{ЦИТИРАНА ЛИТЕРАТУРА}

АлАновић, Миливој. Допуне и додаци: између обавезности и испустивости. Гоgищъак Филозофской факулиетеиа у Новом Саgу XXXVII/2 (2012): 145-162.

АлАновић, Миливој. Реченице са допунском клаузом. Предраг Пипер, Миливој Алановић, Слободан Павловић, Ивана Антонић, Марина Николић, Дојчил Војводић, Људмила Поповић, Срето Танасић, Биљана Марић. Синйакса сложене реченице у савременом срйском језику (у редакцији Предрага Пипера). Нови Сад - Београд: Матица српска Институт за српски језик САНУ, 2018, 91-197.

АлАновић, Миливој. О ойунама и gойуњавању у срйском језику. Нови Сад: Филозофски факултет, 2019.

Антонић, Ивана. Синтакса и семантика падежа. Предраг Пипер, Ивана Антонић, Владислава Ружић, Срето Танасић, Људмила Поповић, Бранко Тошовић. Синйакса савременоїа

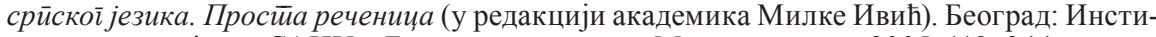
тут за српски језик САНУ - Београдска књига - Матица српска, 2005, 119-344.

БЕлић, Александар. О промењивости радног (прошлог) глаголског продева. Нам језик II/2 (1934): $33-39$.

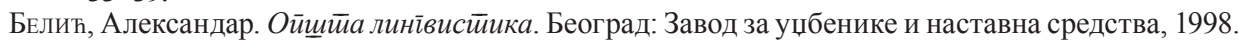


БЕлић, Александар. Истиорија срӣской језика. Београд: Завод за уџбенике и наставна средства, 1999.

ЗолотовА, Галина А. Очерк фуниионального синтаксиса русского языка. Москва: УРСС, 2009. Новокмет, Слободан. Радни глаголски придев у функцији придева - семантичка класификација. Лийар 52 (2013): 63-76.

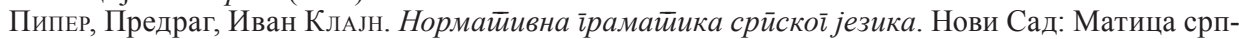
ска, 2013.

Ружић, Владислава. Допунске реченице у савременом српском језику. Зборник Майице срӣске за филолойију и линіввистиику XLIX/1 (2006): 123-217.

Спасолевић, Марина. Радни глаголски придев у систему врста речи.Нам језик XLII/1-2 (2011): 25-39.

Станојчић, Живојин, Љубомир Поповић. Грамат̄ика срӣской језика за иимназије и среgње щколе. Београд: Завод за уџбенике, 2014.

СтевАновит, Михаило. Рефлексивни глаголи и промењивост радног глаголског придева. Нами језик VII (1940): 196-205.

Стевановић, Михаило. Још нешто о придевској функцији радног глаголског придева. Наш језик IX/3-4 (1958): 86-92.

СтевАновић, Михаило. Придевска служба трпних придева од глаголакоји немају тог облика. Нам језик XII/7-10 (1962): 201-208.

ÀGeL, Vilmos. Valenztheorie. Tübingen: Gunter Narr Verlag, 2000.

EIsenberg, Peter. Grundriss der deutschen Grammatik. Band 2: Der Satz. Stuttgart: Metzler, 2013. ENGEL, Ulrich. Syntax der deutschen Gegenwartssprache. Berlin: ESV, 2009.

ERoms, Hans-Werner. Syntax der deutschen Sprache. Berlin - New York: Walter de Gruyter, 2000.

Helbig, Gerhard. Probleme der Valenz- und Kasustheorie. Tübingen: Max Niemeyer Verlag, 1992.

HelBIG, Gerhard. Linguistische Theorien der Moderne. Berlin - Weidler Buchverlag, 2002.

Mrazović, Pavica, Zora VuKadinović. Gramatika srpskog jezika za strance. Novi Sad - Sremski Karlovci: Izdavačka knjižarnica Zorana Stojanovića, 2009.

PAfel, Jürgen. Einführung in die Syntax. Stuttgart - Weimar: J. B. Metzler, 2011.

Radovanović, Milorad. Spisi iz sintakse i semantike. Novi Sad - Sremski Karlovci: Dobra vest - Izdavačka knjižarnica Zorana Stojanovića, 1990.

TAFrA, Branka. Od riječi do rječnika. Zagreb: Školska knjiga, 2005.

TESNiĖRE, Lucien. Éléments de syntaxe structurale. Paris: Éditions Klincksieck, 1959.

Van Valin, Robert, Randy J. La Polla. Syntax. Structure, Meaning and Function. Cambridge: CUP, 1997.

Welke, Klaus M. Einfürung in die Valenz- und Kasustheorie. Leipzig: Bibliographisches Institut, 1988.

Welke, Klaus M. Valenzgrammatik des Deutschen. Eine Einführung. Berlin - New York: De Gruyter, 2011.

Milivoj Alanović

\section{GRAMMATISCHE UND VALENZBEZIEHUNGEN IN SYNTAGMEN}

\section{Zus a m menfassung}

Die Hauptaufgabe dieser Forschung bestand darin, die Aufmerksamkeit zu wecken, dass zwischen Regens und Dependens auch innerhalb verschiedener Arten von Syntagmen die gleiche Art von Valenzbindungen - Komplemente und Supplemente, die sonst für einen einfachen Satz typisch sind, aufgebaut wird, wobei wir uns meist auf Nomen und Adjektive beschränkten. Darüber hinaus widmet sich der zweite Teil der Arbeit den Besonderheiten der Verbvalenz, insbesondere den unpersönlichen Verbformen, wie z.B. Partizipien, und dem grammatikalischen Status ihrer Satelliten.

Универзитет у Новом Саду

Филозофски факултет

Одсек за српски језик и лингвистику

Др Зорана Ђинђића 2, 21000 Нови Сад, Србија

milivoj.alanovic@ff.uns.ac.rs
(Примљено: 31. августа 2021; прихваћено: 28. октобра 2021) 